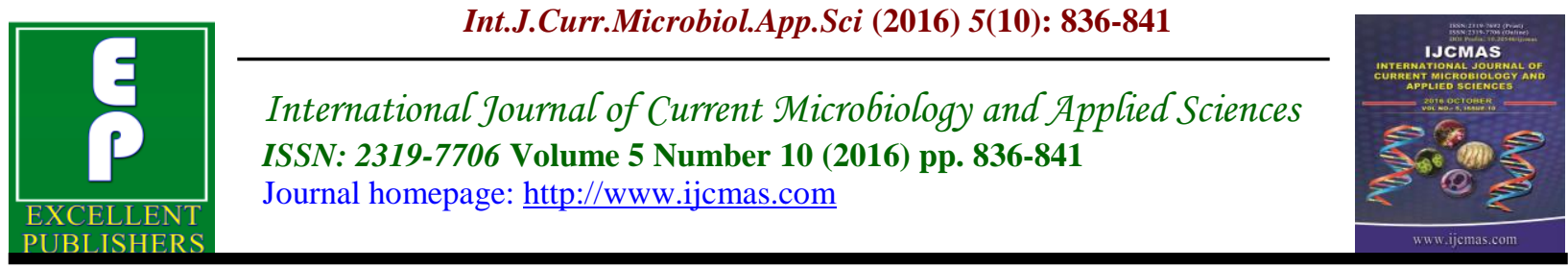

Original Research Article

http://dx.doi.org/10.20546/ijcmas.2016.510.091

\title{
Chemical Composition and Antibacterial Activity of Essential Oils of Tanacetum longifolium
}

\author{
Vinesh Kumar $^{1 *}$ and Yogita Sharma ${ }^{2}$ \\ ${ }^{1}$ Department of Science, Kids' Science Academy, Khubbanpur, Roorkee, Uttarakhand, India \\ ${ }^{2}$ Department of Chemistry, Guru Kashi University, Bathinda, Punjab, India
}

*Corresponding author

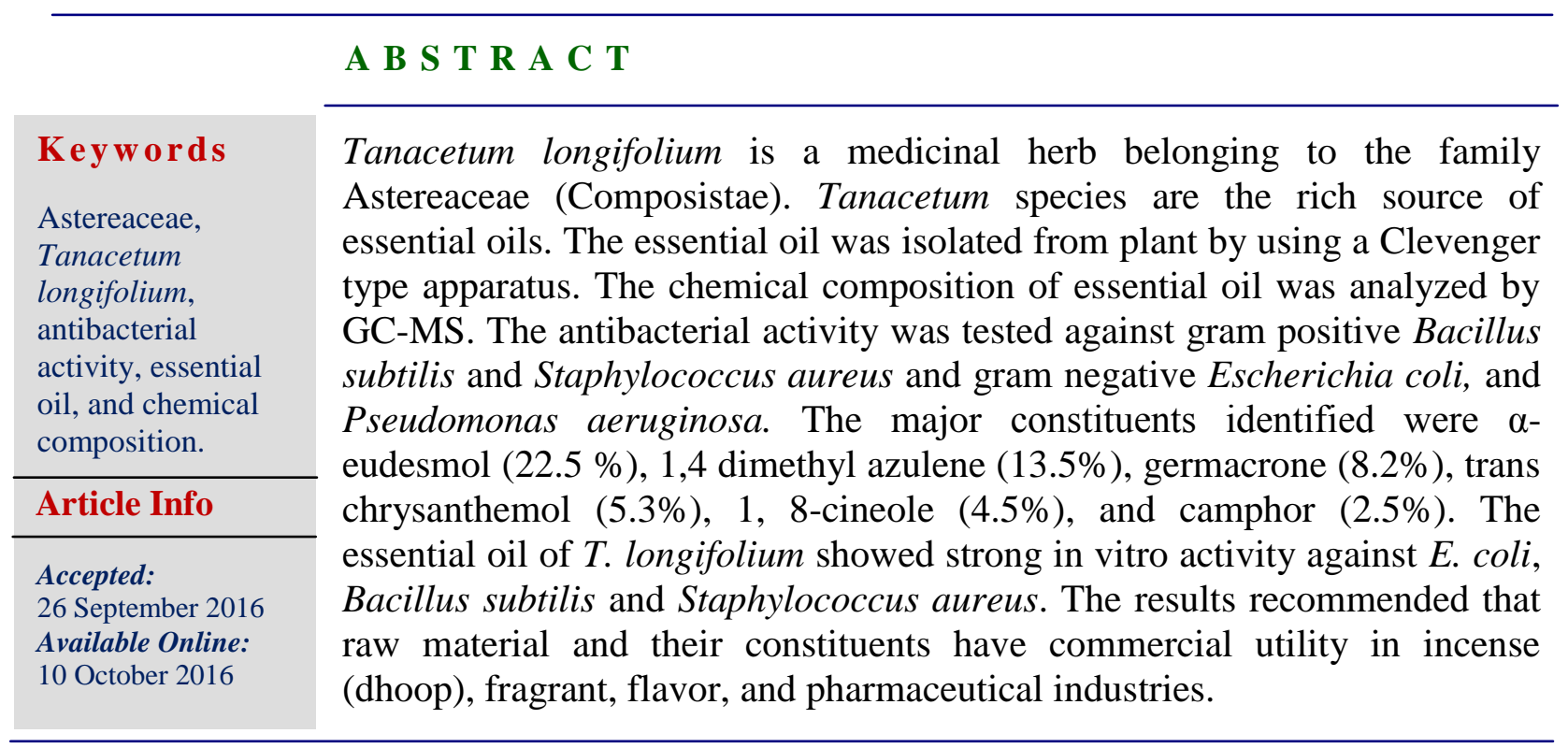

\section{Introduction}

Tanacetum longifolium is a medicinal herb has its place to the family Astereaceae (Composistae). The Asteraceae or Compositae (commonly stated to as the aster, daisy, or sunflower family), is an extremely large and well-known family of vascular plants (Kumar and Tyagi, 2013). The group has more than 22,750 presently recognized species, spread across 1620 genera and 12 subfamilies. The most members of Asteraceae family are herbaceous, but a significant number are also shrubs, vines and trees. The family is spread throughout the world and most common in the arid and semi-arid regions of subtropical and lower temperate latitudes (Kumar and Tyagi, 2013). Concern is increasing in species of Tanacetum due to its essential oils (cordial, stomachic, and used as a food preservative), bitter substances and the presence of sesquiterpene lactones, which revealed biological activities like growth regulating, cytotoxicity, antimicrobial activity (Coron et al., 1992). 
The plants of genus Tanacetum have been used as expectorants, vermifuges, antiseptic and spasmolytics in popular medicine (Oksuz, 1990). The dry leaves and flowers of T. vulgare are used as antiseptic and spasmodic and for defensive against dandruff in Bulgaria, (Nano et al., 1979). The leaves of $T$. parthenium are used as a popular British traditional herbal therapy for the prophylaxis of migraine (Kubo and Kubo, 1995).

The genus Tanacetum is signified by six species viz. Tanacetum nubigenum, Tanacetum tibeticum, Tanacetum longifolium, Tanacetum arteminiodes, Tanacetum gracile, and Tanacetum senecionis in Kumaon and Garhwal regions at 3600- $4300 \mathrm{~m}$ elevation (Strachey, 1852). These herbs grow in gardens wast area or along road sides, forest shades, creek banks, river-gravels, margins or fields, pasturelands, on mountain steeps, limestone rocks, slopes, crevices and screes.

Chemotherapeutic agents are widely used as antimicrobial agents. One of the major problems in antimicrobial chemotherapy is the increasing incidence of resistance to antibiotics, which leads to the deficiency of antimicrobial treatment. The overuse of antibiotics and consequent antibiotic selection pressure is thought to be the most important factor contributing to the appearance of different kinds of resistant microbes. Species of various plants are used as antimicrobial agents worldwide (Kumar and Tyagi, 2013). This study was an attempt to explore the antibacterial potential of Tanacetum longifolium essential oil.

The literature review of the genus Tanacetum shows that no previous work reported on antibacterial activities of essential oil of Tanacetum longifolium (Kumar and Tyagi, 2013). Therefore, present research work was undertaken to study the chemical composition, and antibacterial activity of Tanacetum longifolium.

\section{Materials and methods}

\section{Plant collection}

The plants were collected from the Alpine slope of Kumaun Himalaya of Uttarakhand State, India. The plant was identified as Tanacetum longifolium by the Department of Botany, D.A.V. (P.G.) College, Dehradun, Uttarakhand. Freshly picked tissue stored in dry plastic bags during the several days required for transport. The voucher specimen was also deposited in the Herbarium of Department of Botany, D.A.V. (P.G.) College, Dehradun, Uttarakhand.

\section{Isolation and analysis of essential oil}

Air dried plant material (500g) was hydrodistilled for 4 hours using a Clevenger type apparatus. The oil was dried over anhydrous sodium sulphate $\left(\mathrm{Na}_{2} \mathrm{SO}_{4}\right)$ and then isolated oil was kept in a sealed vial in refrigerator until analysis. The chemical composition of essential oil was analyzed by GC-MS. The components of the oil of $T$. longifloium were recognized by comparison of their mass spectra with those of a computer library and with authentic compounds. Further they were also confirmed by comparison of their retention indices either with those of authentic compounds amd with data published in literature (Davies, 1990, Ateya (1992), Shibamoto, 1987 and Adams, 2001).

\section{Antibacterial activity}

The antibacterial activity was determined with the agar well diffusion method (Kumar and Tyagi, 2013). The bacterial strains selected were gram positive Bacillus subtilis 
and Staphylococcus aureus and Escherichia coli, and Pseudomonas aeruginosa.

A loopful of $10^{4}-10^{6}$ suspension of 24 hour old broth of each bacterium was streaked on the surface of Muller-Hinton agar plates. Wells were dug in the agar with the help of a sterile cork borer. Stock solutions of the compounds or crude extracts containing $2 \mathrm{mg} / \mathrm{ml}$ were prepared in sterile dimethyl sulfoxide (DMSO). Dillutions of the stock

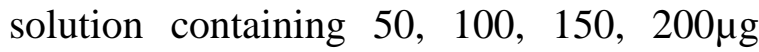
were prepared in DMSO. 100 $\mu$ l of each dilution was then added in the respective wells. The plates were then incubated at the $37^{\circ} \mathrm{C}$ for 24 hour and zones of inhibition were measured in millimeters. Penicillin was used as standard antibiotics to compare the extent of activity of the test samples.

\section{Results and Discussion}

\section{Identification of essential oil constituents}

The identified chemical constituents of the essential oil of $T$. longifloium are given in table 1 in order of their retention index. Total 37 compounds $(86 \%$ of the total constituents of oil) were identified from the oil of $T$. longifolium. The major constituent was $\alpha$-eudesmol (22.5\%), 1,4 dimethyl azulene $(13.5 \%)$, germacrone $(8.2 \%)$, trans chrysanthemol $(5.3 \%), 1,8$-cineole $(4.5 \%)$, and camphor (2.5\%). The results recommended that raw material and their constituents have commercial utility in incense (dhoop), fragrant, flavor, and pharmaceutical industries.

The essential oil isolated from Tanacetum longifolium had shown antibacterial activity against tested bacterial species (Table-2 and Figure-1). The antimicrobial activity of essential oils of Tanacetum longifolium against some bacteria was found as moderate. The results indicated that the essential oils of both Tanacetum species essential oils used in this study inhibited development of bacteria at different ratios. In general, the antimicrobial activity of the essential oil tested was more pronounced against Gram-positive than against Gram negative bacteria. This type of results are also observed from the studies with essential oils from many other plant species (Ouattara et al., 1997 and Nostro, 2000).

Table.1 Chemical composition of essential oil of Tanacetum longifolium

\begin{tabular}{|c|l|c|c|}
\hline S. No. & \multicolumn{1}{|c|}{ Compounds } & RRI & Percentage \\
\hline 1 & Tricyclene & 927 & 0.9 \\
\hline 2 & $\alpha$ - pinene & 936 & 0.1 \\
\hline 3 & Camphene & 950 & 0.2 \\
\hline 4 & Sabinene & 973 & 0.1 \\
\hline 5 & $\beta$ - pinene & 978 & 0.3 \\
\hline 6 & Verbenene & 982 & 0.2 \\
\hline 7 & $\alpha$ - terpinene & 1013 & 0.2 \\
\hline 8 & 1,8 - cineole & 1038 & 4.5 \\
\hline 9 & Limonene & 1025 & 0.1 \\
\hline 10 & (z)- $\beta$-ocimene & 1029 & 1.5 \\
\hline 11 & Trans- sabenene hydrate & 1053 & 0.5 \\
\hline 12 & Furanoid & 1058 & 0.7 \\
\cline { 3 - 4 }
\end{tabular}




\begin{tabular}{|l|l|c|c|}
13 & Linalool & 1086 & 2.3 \\
\hline 14 & Camphor & 1123 & 2.5 \\
\hline 15 & Trans-chrysanthemol & 1153 & 5.3 \\
\hline 16 & n-decanal & 1180 & 0.1 \\
\hline 17 & Geraniol & 1235 & 0.2 \\
\hline 18 & Decanol & 1264 & 0.2 \\
\hline 19 & Eugenol & 1331 & 0.5 \\
\hline 20 & $\alpha$ - isocomene & 1389 & 0.8 \\
\hline 21 & Germacrene-D & 1479 & 2.3 \\
\hline 22 & $\beta$ - Vetisperene & 1486 & 0.2 \\
\hline 23 & 2-tridecanol & 1490 & 1.4 \\
\hline 24 & $\alpha$-salinene & 1494 & 0.8 \\
\hline 25 & Germacrene A & 1503 & 0.3 \\
\hline 26 & $\delta$-Cadinene & 1520 & 0.2 \\
\hline 27 & 1,4 - dimethylazulene & 1532 & 13.5 \\
\hline 28 & Caryophlene oxide & 1578 & 3.1 \\
\hline 29 & Valgarone A & 1580 & 0.4 \\
\hline 30 & Tetradecanal & 1596 & 2.8 \\
\hline 31 & Cedrol & 1603 & 0.3 \\
\hline 32 & Furanogermacrene & 1624 & 2.5 \\
\hline 33 & $\alpha$ - eudesmol & 1653 & 22.5 \\
\hline 34 & $\alpha$-barbatenal & 1659 & 2.5 \\
\hline 35 & Germacrone & 1684 & 8.2 \\
\hline 36 & $\alpha$-Santalol acetate & 1756 & 0.8 \\
\hline 37 & Dihydrodiplophylline & 1896 & 3 \\
\hline & & & $\mathbf{8 6}$ percent \\
\hline
\end{tabular}

Table.2 Antibacterial activity of extracts and essential oil of Tanacetum longifolium

\begin{tabular}{|c|c|c|}
\hline \multirow{2}{*}{ Organisms } & Zone of inhibition (in mm) \\
\cline { 2 - 3 } & control & essential oil \\
\hline \multicolumn{3}{|c|}{ Gram positive } \\
\hline Bacillus subtilis & 16 & 13 \\
\hline Staphylococcus aureus & 14 & 15 \\
\hline \multicolumn{2}{|c|}{ Gram negative } \\
\hline Escherichia coli & 15 & 14 \\
\hline Pseudomonas aeruginosa & 12 & 12 \\
\hline
\end{tabular}


Fig.1

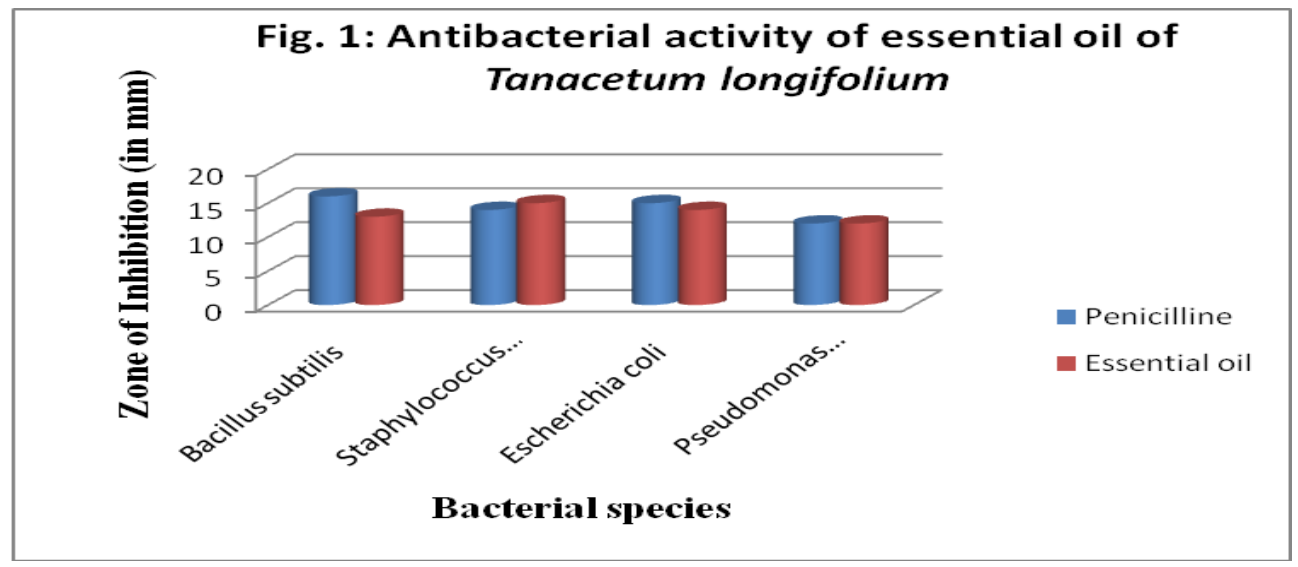

Penicillin was used as standard antibiotics to compare the extent of activity of the test samples. It is interesting that $T$. longifolium essential oil was showed similar antimicrobial activity against the microorganisms as in antibiotic. The essential oil of $T$. longifolium showed strong in vitro activity against E. coli, Bacillus subtilis and Staphylococcus aureus.

In conclusion, the amount of essential oil obtained by hydrodistilation from $T$. longifolium in full flowering stage was 0.92 percent of the dried weight. Total 37 compounds $(86 \%$ of the total constituents of oil) were identified from the oil of $T$. longifolium. The major constituent was $\alpha$ eudesmol (22.5 \%), 1,4 dimethyl azulene (13.5\%), germacrone (8.2\%), trans chrysanthemol (5.3\%), 1, 8-cineole (4.5\%), and camphor (2.5\%). The results recommended that raw material and their constituents have commercial utility in incense (dhoop), fragrant, flavor, and pharmaceutical industries.

\section{References}

Adams, R.P. 2001. Quadrupolc Mass Spectroscopy. Allured Publ. Crop., Carol Stream, IL.
Ateya, A.M. 1992. "GC-MS analysis of the volatile oil of Pyrethrum santolinoides. Az. J. Nat. Prod., 8: 8288.

Coron, N., Bozok-Johanson, C., Jakupovic, J., Lin, L.J., Shieh, H.L., Cordell, G. A. and Celik, N. 1992. Sesquiterpene lactones with antibacterial activity from Tanacetum. Phytochem., 31: 101-104.

Davies, N.W. 1990. Gas chromatographic retention indices of monoterpenes and sesquiterpenes on methyl silicone and Carbowax $20 \mathrm{M}$ phases. $J$. Chromatogr., 503: 1-24.

Kubo, A. and Kubo, I. 1995. Antimicrobial Agents from Tanacetum balsamita. $J$. Nat. Prod., 58(10): 1565-1569.

Kumar, V. and Tyagi, D. 2013. Antifungal activity evaluation of different extracts of Bergenia stracheyi. Int. J. Curr. Microbiol. App. Sci., 2(7): 69-78.

Kumar, V. and Tyagi, D. 2013. Chemical Composition and Biological Activities of Essential Oils of Genus Tanacetum - a review. J. Pharmacognosy and Phytochem., 2(3): 155-159.

Kumar, V. and Tyagi, D. 2013. Review on phytochemical, ethnomedical and biological studies of medically useful genus Bergenia. Int. J. Curr. Microbiol. App. Sci., 2(5): 328-334. 
Nano, G.M., Bicchi, C., Frattini, C. and Gallino, M. 1979. The composition of some oils from Artemisia vulgaris. Planta Med., 35: 270-274.

Nostro, A., Germano, M.P., Angelo, V., Marino, A. and Cannatelli, M. 2000. Extraction methods and bioautography for evaluation of medicinal plant antimicrobial activity. Letters in Appl. Microb., 30: 379-384.

Oksuz, S. 1990. Sesquiterpenoids and other constituents from Tanacetum cilicium. Phytochem., 29(3): 887-890.
Ouattara, B., Simard, R.E., Holley, R.A., Piette, G.J.P. and Begin, A. 1997. Antibacterial activity of selected fatty acids and essential oils against six meat spoilage organisms. Int. J. Food Microb., 37: 155-162.

Shibamoto, T. 1987. Retention indices in essential oil analysis. Alfred HeuthigVerlag: New York, 259-275.

Strachey, R. 1852. Periodical Experts, New Delhi, India. pp 92.

\section{How to cite this article:}

Vinesh Kumar and Yogita Sharma. 2016. Chemical Composition and Antibacterial Activity of Essential Oils of Tanacetum longifolium. Int.J.Curr.Microbiol.App.Sci. 5(10): 836-841. doi: http://dx.doi.org/10.20546/ijcmas.2016.510.091 